\title{
Analisis pengaruh tingkat suku bunga, kredit macet dan capital adequacy ratio (CAR) terhadap penyaluran kredit modal kerja Bank Umum di Indonesia
}

\author{
Rahma Nurjanah*; Nurul Arida \\ Prodi Ekonomi Pembangunan Fak. Ekonomi dan Bisnis Universitas Jambi \\ *E-mail korespondensi:rahma_nurjanah@unja.ac.id
}

\begin{abstract}
This study aims to determine and analyze interest rates on credit, bad credit, CAR, and lending to commercial banks in Indonesia. In addition, it is also to study the effect of lending rates, bad credit, and CAR on commercial bank lending in Indonesia in 20102018. The analytical method used in this research is descriptive quantitative. This study uses multiple linear regression analysis tools. The results of this study indicate that the interest rate, bad credit, and CAR variables simultaneously influence lending. Partially the interest rate variable has a negative and significant effect on lending. The nonperforming loan variable has a negative and significant impact on credit distribution. The variable CAR has a positive and significant impact on lending.
\end{abstract}

Keywords: Landing, The interest rate on loans, Bad loans, CAR

\begin{abstract}
Abstrak
Penelitian Ini bertujuan untuk mengetahui dan menganalisis perkembangan tingkat suku bunga kredit, kredit macet, CAR dan penyaluran kredit pada bank umum di Indonesia. Selain itu juga untuk menganalisis pengaruh tingkat suku bunga kredit, kredit macet dan CAR terhadap penyaluran kredit bank umum di Indonesia tahun 2010-2018. Metode analisis yang digunakan dalam penelitian ini adalahdeskriptif kuantitatif. Penelitian ini menggunakan alat analisi regresi linier berganda. Hasil penelitian ini menunjukkan secara simultan variabel tingkat suku bunga, kredit macet dan CAR berpengaruh terhadap penyaluran kredit. secara parsial variabel tingkat suku bunga berpengaruh negatif dan signifikan terhadap penyaluran kredit. Variabel kredit macet berpengaruh negatif dan signifikan terhadap penyaluran kredit. VariabelCAR berpengaruh positif dan signifikan terhadap penyaluran kredit.
\end{abstract}

Kata kunci: Penyaluran kredit, Tingkat suku bunga kredit, Kredit macet, CAR

\section{PENDAHULUAN}

Bank berperan sebagai institusi keuangan yang memainkan peran penting dalam mendorong pertumbuhan ekonomi, pemerataan pendapatan, pengentasa kemiskinan dan melaksanakan fungsi intermediasi karena bank dapat menjangkau seluruh lapisan masyarakat. Kegagalan sistem keuangan akan berpengaruh pada melemahnya kinerja seluruh sistem perekonomian. Apabila sistem keuangan tidak stabil dan tidak berfungsi secara efisien, pengalokasian dana tidak akan berjalan dengan baik sehingga dapat menghambat pertumbuhan ekonomi (Kusumangnituti dan Cecep,2018). Ketika sektor 
perbankan mengalami keterpurukan maka hal ini juga akan berdampak pada perekonomian Indonesia yang ikut terpuruk.

Pembangunan nasional suatu bangsa mencakup didalamnya pembangunan ekonomi, dalam pembangunan ekonomi diperlukan peran serta lembaga keuangan untuk membiayai, karena dalam pembangunan sangat diperlukan tersedianya dana (Kuncoro dan Suhardjono,2002). Artinya, pembangunan ekonomi di suatu negara sangat bergantung pada kontribusi dari sektor perbankan. Perbankan adalah media yang menjembatani antara sektor moneter dengan sektor riil (Wardhani,2011). Dengan adanya penyaluran kredit ini para pelaku usaha dapat mengembangkan usahanya sehingga menimbulkan penciptaan lapangan kerja, peningkatan pendapatan masyarakat yang akan berdampak pada peningkatan kesejahteraan masyarakat.

Penyaluran kredit merupakan salah satu aktivitas bank umum yang paling utama dalam menghasilkan keuntungan (Greydi,2013). Keuntungan ini diperoleh dari tingkat suku bunga yang ditetapkan perbankan sebagai balas jasa atau harga yang harus dibayar oleh debitur atas pinjamannya. Oleh karena itu, tingginya tingkat suku bunga akan menurunkan permintaan kredit sehingga penyaluran kredit pun menurun. Penetapan tingkat suku bunga dalam penyaluran kredit ini berpengaruhterhadap investasi, semakin kecil tingkat suku bunga yang ditetapkan akan semakin besar keinginan seseorang untuk berinvestasi begitupun sebaliknya semakin besar tingkat suku bunga maka semakin kecil pula keinginan seseorang untuk berinvestasi. Hal ini dikarenakan jika seseorang berinvestasi pada saat tingkat suku bunga tinggi maka akan memberatkan para investor membayar beban bunga dari penyaluran kredit sehingga akan mempengaruhi besarnya keuntungan yang diperoleh dari investasi.

Meskipun tujuan utama dari penyaluran kredit untuk memperoleh profitabilitas namun, risiko kerugian yang akan dialami oleh bank dari penyaluran kredit juga besar. Karena, setiap penyaluran kredit yang dilakukan bank memiliki risiko adanya kredit bermasalah, yaitu kredit yang telah disalurkan mengalami masalah dalam pengembaliannya baik itu pembayaran pinjaman pokok ataupun pembayaran suku bunga yang tidak sesuai dengan jangka waktu yang sudah ditetapkan hal ini biasa disebut dengan kredit macet. Rasio NPL (Non Perfoarming Loan) digunakan dalam dunia perbankan sebagai gambaran untuk mengukur seberapa besar persentase kredit macet yang dihasilkan dari penyaluran kredit oleh perbankan. Bank Indonesia menetapkan rasio wajar batas NPL yakni sebesar 5\% dari total portofolio kreditnya. Semakin kecil rasio NPL maka kinerja perbankan dalam menjaga kualitas kreditnya semakin baik begitupun sebaliknya. Kredit bermasalah yang tinggi dapat menimbulkan keengganan bank untuk menyalurkan kredit karena harus membentuk cadangan penghapusan yang besar, sehingga mengurangi jumlah kredit yang diberikan oleh suatu bank (Arif,2017). Karena adanya kredit macet ini bank harus memiliki modal yang cukup untuk menutupi kerugian yang disebabkan kredit macet dan agar bank tetap bisa menjalankan kegiatan usahanya sebagai lembaga keuangan.

Modal dalam dunia perbankan disebut dengan Capital Adequacy Ratio (CAR). Permodalan atau yang sering diukur dengan Capital Adequacy Ratio (CAR) merupakan rasio kinerja bank untuk mengukur kecukupan modal yang dimiliki bank untuk menunjang aktiva yang mengandung atau menghasilkan risiko misalnya, penyaluran kredit (Dendawijaya,2009). Tingkat kecukupan modal sangat bergantung pada portofolio asetnya (Taswan,2010). Artinya semakin besar rasio CAR yang dimiliki oleh suatu bank, maka semakin besar pula kemampuan bank tersebut untuk menyalurkan kreditnya. Hal ini dikarenakan ketika rasio CAR suatu bank tinggi, maka bank tersebut memiliki sumber financial yang besar untuk menutupi kerugiannya. 
Tabel 1. penyaluran kredit, tingkat suku bunga, kredit macet dan CAR Tahun 2014.I 2018.IV.

\begin{tabular}{cccccc}
\hline Tahun & Triwulan & $\begin{array}{c}\text { Penyaluran kredit } \\
\text { (miliar rupiah) }\end{array}$ & $\begin{array}{c}\text { Suku } \\
\text { bunga }(\%)\end{array}$ & $\begin{array}{c}\text { Kredit } \\
\text { macet (\%) }\end{array}$ & CAR (\%) \\
\hline \multirow{2}{*}{014} & Triwulan I & $1,572,862$ & 12.37 & 2.36 & 19.77 \\
& Triwulan II & $1,650,529$ & 12.63 & 2.43 & 19.45 \\
& Trwiulan III & $1,708,471$ & 12.78 & 2.55 & 19.53 \\
& Triwulan IV & $1,757,449$ & 12.79 & 2.49 & 19.57 \\
\hline \multirow{2}{*}{015} & Triwulan I & $1,729,294$ & 12.82 & 2.78 & 20.98 \\
& Triwulan II & $1,828,058$ & 12.70 & 2.98 & 20.28 \\
& Trwiulan III & $1,891,535$ & 12.58 & 3.19 & 20.62 \\
& Triwulan IV & $1,916,256$ & 12.46 & 2.99 & 21.39 \\
\hline 2016 & Triwulan I & $1,848,712$ & 12.28 & 3.54 & 22.00 \\
& Triwulan II & $1,961,581$ & 11.82 & 3.74 & 22.56 \\
& Trwiulan III & $1,971,580$ & 11.61 & 3.73 & 22.60 \\
& Triwulan IV & $2,049,098$ & 11.36 & 3.59 & 22.93 \\
\hline 2017 & Triwulan I & $2,007,858$ & 11.19 & 3.70 & 22.88 \\
& Triwulan II & $2,103,048$ & 11.12 & 3.49 & 22.74 \\
& Trwiulan III & $2,130,383$ & 10.99 & 3.47 & 23.25 \\
& Triwulan IV & $2,222,809$ & 10.68 & 3.18 & 23.18 \\
\hline 2018 & Triwulan I & $2,185,021$ & 10.59 & 3.34 & 22.65 \\
& Triwulan II & $2,344,924$ & 10.49 & 3.19 & 22.01 \\
& Trwiulan III & $2,423,637$ & 10.59 & 3.20 & 22.91 \\
& Triwulan IV & $2,512,476$ & 10.34 & 2.81 & 22.97 \\
\hline
\end{tabular}

Sumber data: Otoritas Jasa Keuangan (OJK) dan Bank Indonesia (BI) (diolah)

Berdasarkan Tabel 1 penyaluran kredit modal kerja bank umum pada periode 2014-2018 cenderung terus meningkat, namun pada setiap triwulan I perkembangan penyaluran kredit cenderung lebih kecil dibandingkan dengan triwulan IV tahun sebelumnya, hal ini disebabkan karena adanya siklus yang umum terjadi yaitu ketika penyaluran kredit di akhir tahun meningkat maka hal ini akan menyebabkan penurunan penyaluran kredit di awal tahun. Penyaluran kredit yang terus meningkat ini juga didukung oleh tingkat suku bunga yang cenderung menurun pada periode ini.

Pada triwulan II tahun 2014 tingkat suku bunga mengalami peningkatan hingga triwulan I tahun 2015, peningkatan tingkat suku bunga diikuti dengan peningkatan penyaluran kredit. Pada dasarnya peningkatan tingkat suku bunga akan mempengaruhi permintaan kredit. Berdasarkan teori hubungan antara tingkat suku bunga dan kredit ini adalah negatif. Namun pada kenyatannya yang terjadi di Indonesia pada periode ini peningkatan tingkat suku bunga juga diikuti dengan peningkatan penyaluran kredit, hal ini tentunya bertentangan dengan teori dan menarik perhatian para peneliti untuk menganalisis penyaluran kredit di Indonesia.

Penyaluran kredit yang disalurkan oleh perbankan tentunya akan ada risiko kredit macet. Kredit bermasalah merupakan kondisi yang ditakuti oleh pegawai bank karena kondisi ini akan menyebabkan penurunan pendapatan bank yang akan berdampak pada penurunan laba, sehingga perbankan akan mengurangi jumlah penyaluran kreditnya ketika persentase kredit macet meningkat (Kuncoro dan Suhardjono, 2002). Sehingga besarnya rasio kredit macet yang dimiliki oleh suatu bank akan menurunkan penyaluran kredit oleh perbankan. Selain itu, bagi nasabah yang tercatat gagal mengembalikan kredit nasabah tersebut tidak bisa lagi meminta penyaluran kredit pada bank karena 
bank akan lebih selektif menyalurkan kreditnya. Namun pada tabel 1, ketika persentase kredit macet meningkat penyaluran kredit pun juga meningkat.

Persentase CAR pada periode ini berfluktuasi namun cenderung meningkat. Kecukupan modal yang tinggi akan menyebabkan perbankan memiliki sumber daya financial yang besar untuk menutupi aktiva yang beresiko seperti penyaluran kredit, sehinggga semakin besar modal yang dimiliki oleh suatu perbankan maka kemampuan bank untuk menyalurkan kredit pun akan semakin besar. Pada tabel 1, persentase CAR pada periode tahun 2014-2018 berfluktuasi dan cenderung meningkat serta secara keseluruhan persentase CAR pada periode ini berada diatas jumlah persentase minimum yang harus dimiliki oleh bank yaitu sebesar $8 \%$. Sehingga bank memiliki kemampuan yang besar untuk menyalurkan kreditnya..

\section{METODE}

\section{Jenis dan sumber data}

Jenis data yang digunakan dalam penelitian ini adalah data sekunder, berupa data time series (runtun waktu) dalam bentuk tiruwlan periode 2010.I-2018.IV. Data-data dalam penelitian ini bersumber dari Bank Indonesia (BI) dan Otoritas Jasa Keuangan (OJK) yang telah dipublikasi melalui website resmi dari intitusi tersebut.

\section{Metode analisis data}

Analisis deskriptif digunakan untuk menjawab tujuan pertama. Menganalisis data dengan cara mendeskripsikan atau menggambarkan data yang telah terkumpul sebagaimana adanya tanpa bermaksud membuat kesimpulan yang berlaku untuk umum dan generalisasi (Sugioyo,2018). Data yang dideskripsikan dalam penelitian ini yaitu data dari dari variabel-variabel yang digunakan dalam penelitian (tingkat suku bunga, kredit macet, CAR dan penyaluran kredit) dengan menggunakan rumus perkembangan.

Analisis kuantitatif digunakan untuk menjawab tujuan penelitian kedua, untuk melihat bagaimana pengaruh tingkat suku bunga, kredit macet dan CAR terhadap penyaluran kredit. Alat analisis yang digunakan adalah regresi linier berganda. Berikut merupakan persamaan model regresi berganda yang digunakan dalam penelitian :

$$
\mathrm{Y}=\beta 1 \mathrm{X} 1+\beta 2 \mathrm{X} 2+\beta 3 \mathrm{X3}+\mathrm{e}
$$

Keterangan :

Y $\quad=$ Penyaluran kredit

B1 $-\beta 2=$ Koefisien parameter

SBK = Tingkat suku bunga

$\mathrm{KM} \quad=$ Kredit macet (NPL)

$\mathrm{CAR}=$ Capital adequacy ratio $(\mathrm{CAR})$

$\mathrm{e} \quad=$ Error term (variabel pengganggu)

\section{Uji asumsi klasik}

\section{Uji normalitas}

Uji normalita bertujuan untuk menguji apakah dalam model regresi variabel terikat dan variabel bebas memiliki distribusi normal atau tidak. Untuk melihat apakah data yang berdistribusi normal atau tidak dapat dilakukan dengan uji Jaeque-Bera (JB Tst). Dengan dasar pengambilan keputusana apabila Probabilitas Jb hitung $>\alpha(5 \%)$ 
maka data berdistribusi normal, begitupun sebaliknya apabila Probabilitas $\mathrm{Jb}$ hitung $<\alpha$ $(5 \%)$ maka data tidak berdistribusi secara normal.

\section{Uji multikolinearitas}

Uji multikolinieritas bertujuan untuk menguji apakah dalam model regresi linier terdapat korelasi antara kesalahan pengganggu periode $t$ dengan kesalahan pengganggu pada periode t-1 (sebelumnya) (Ghozali, 2006). Multikolinieritas berarti adanya hubungan linier yang kuat antar variabel bebas yang satu dengan yang lain dalam model regresi. Metode untuk mengukur kolinearitas adalah dengan menggunakan Variance Inflationary Factor (VIF) untuk setiap variabel bebas yang ada. Untuk mendekteksi adanya multikolinearitas bisa dilihat besaran nilai VIF dan tolerance, suatu model regresi dapat dikatakan bebas multikoliniearitas jika nilai $\mathrm{TOL} \leq 10$.

\section{Uji autokorelasi}

Model regresi yang baik adalah yang bebas dari autokorelasi. Untuk menguji apakah suatu regresi terdapat autokorelasi melakukan pengujian uji Breusch-Godfrey dengan membandingkan antara Probabilita Obs Chi-Square dengan tingkat $\alpha(5 \%)$. Apabila Probabilita Obs Chi-Square lebih besar dari alfa (5\%) maka terbebas dari autokorelasi begitupuun sebaliknya apabila Probabilita Obs Chi-Square lebih kecil dari tingkat alfa maka penelitian tersebut terdapat autokorelasi.

\section{Uji heterokedastisitas}

Uji heterokedastisitas dilakukan dengan tujuan mengetahui apakah variabel ganggguan mempunyai varian yang tidak konstan. Pada uji heteroskedastisitas terdapat beberapa pengujian yang dapat dilakukan salah satunya yang paling digunakan adalah uji white heteroscedasticity. Apabila nilai Probabilitas (Obs* R squared) $>\alpha(0.05)$, maka dapat disimpulkan bahwa model tersebut tidak terdapat heteroskedastisitas.

\section{Uji hipotesis}

\section{Uji F-statistik}

Pengujian ini bertujuan untuk mengetahui pengaruh semua variabel independen terhadap variabel dependent secara signifikan. Pengujian ini dapat dilakukan melalui pengamatan nilai signifikan $\mathrm{F}$ pada tingkat $\alpha$ yang digunakan (penelitian ini menggunakan tingkat $\alpha$ sebesar 5\%). Analisis didasarkan pada pembandingan antara nilai signifikansi 0,05 di mana syarat-syaratnya yaitu : 1) Jika signifikansi $\mathrm{F}<0,05$ maka Ho ditolak yang berarti variabel-variabel independent secara simultan berpengaruh terhadap variabel dependent. 2) Jika signifikansi $F>0,05$, maka Ho diterima yaitu variabel-variabel secara simultan tidak berpengaruh terhadap variabel dependent.

\section{Uji t-statistik}

Tujuan pengujian ini adalah untuk mengetahui apakh masing-masing variabel independent mempengaruhi variabel dependent secara signifikan. Pengujian ini dilakukan dengan uji t atau t-test, yaitu membandingkan antar t-hitung dengan t-tabel. Uji ini dilakukan dengan syarat: a).Jika t-tabel < t-hitung, maka Ho diterima yaitu variabel independent tidak berpengaruh signifikan terhadap variabel dependent. b).Jika t-hitung > t-tabel atau t-hitung - t-tabel, maka Ho ditolak yang berarti variabel independent berpengaruh signifikan terhadap variabel dependent. 
Pengujian juga dapat dilakukan melalui pengamatan nilai signifikansi t pada tingkat $\alpha$ yang digunakan (penelitian ini menggunakan tingkat $\alpha$ sebesar 5\%). Analisis didasarkan pada perbandingan antara signifikan t dengan nilai signifikansi 0,05 , di mana syarat-syaratnya adalah sebagai berikut: a)Jika signifikansi $\mathrm{t}<0,05$, maka Ho ditolak yang berarti variabel independennya berpengaruh signifikan terhadap variabel dependen. b).Jika signifikansi $t>0,05$, maka Ho diterima yaitu variabel independen tidak berpengaruh terhadap variabel dependen.

\section{Uji koefisiean determinasi $\left(\mathbf{R}^{2}\right)$}

Uji $\mathrm{R}^{2}$ pada intinya mengatur seberapa jauh kemampuan model dalam menerangkan variasi variabel dependen. Dimana $R^{2}$ nilainya berkisar antara $0<R^{2}<1$, semakin besar $\mathrm{R}^{2}$ maka variabel bebas semakin dekat hubungannya dengan variabel tidak bebas, dengan kata lain model tersebut dianggap baik (Ghozali, 2006). Nilai yang mendekati satu berarti variabel-variabel independen memberikan hamper semua informasi yang dibutuhkan untuk memprediksi variasi variabel dependen.

\section{HASIL DAN PEMBAHASAN}

\section{Perkembangan penyaluran kredit}

Bagi perbankan, tujuan utama penyaluran kredit bertujuan untuk memperoleh profitabilitas. Profitabilitas ini diperoleh dari tingkat suku yang ditetapkan sebagai balas jasa atas penyalaruan kredit yang telah dilakukan. Semakin tinggi tingkat suku bunga yang ditetapkan maka semakin rendah minat seseorang untuk meminta penyaluran kredit. Setiap Penyaluran kredit yang dilakukan oleh bank memiliki risiko adanya kredit bermasalah atau kredit macet untuk mengatasi ini maka bank harus memiliki modal yang cukup untuk mengantisipasi kerugian yang disebabkan kredit macet agar bank tetap bisa menjalankan usahanya sebagai lembaga keuangan. Rasio CAR adalah gambaran kemampuan bank untuk menutupi kerugian yang disebabkab dari kredit, semakin besar rasio CAR semakin besar pula kemampuan bank menyalurkan kreditnya. Sehingga selain tingkat suku bunga, penyaluran kredit juga dipengaruhi oleh rasio kredit macet dan CAR.

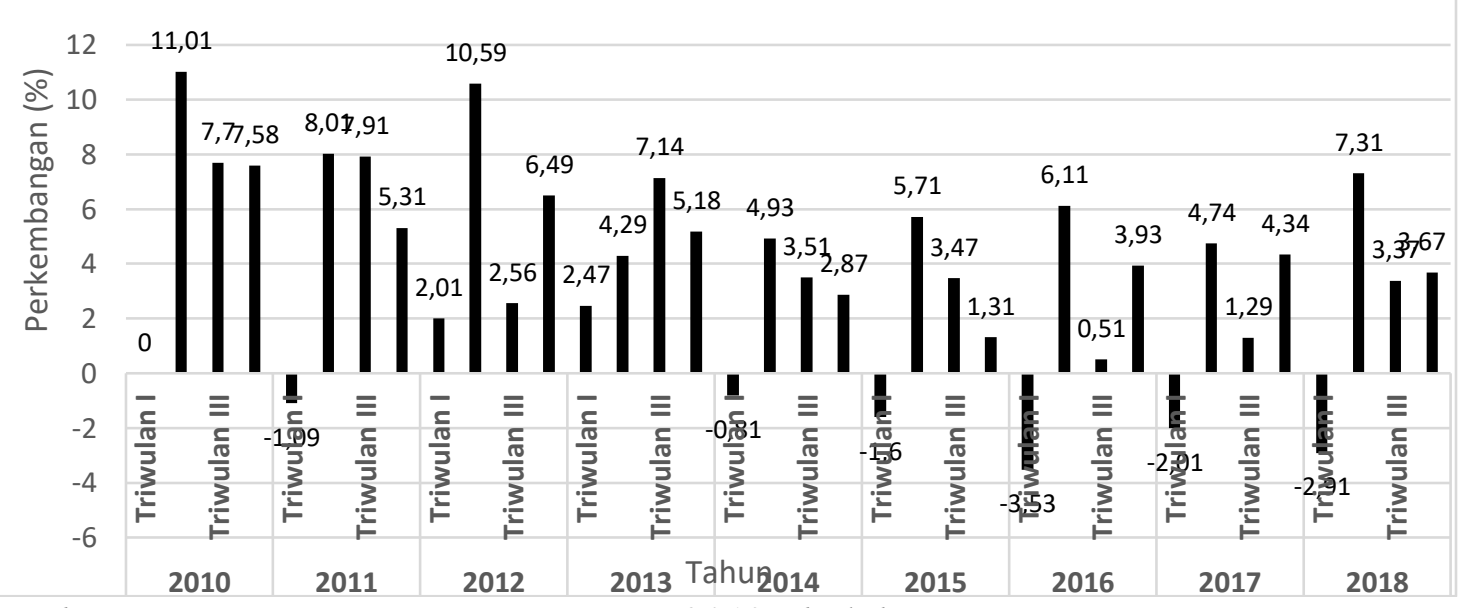

Sumber: Otoritas Jasa Keuangan (OJK), 2019 (diolah)

Grafik 1. Perkembangan penyaluran kredit modal kerja Bank Umum di Indonesia Periode 2010.I-2018.IV.

Berdasarkan Grafik 1 rata-rata penyaluran kredit modal kerja pada periode 2010.I2018.IVsebesar 4,27\%. Perkembangannya penyaluran kredit modal kerja pada periode 
ini berfluktuasi namun untuk jumlah total penyalurannya, penyaluran kredit modal kerja cenderung meningkat. Peningkatan penyaluran kredit modal kerja pada bank umum periode ini juga didukung dengan tingkat suku bunga yang cenderung menurun, persentase kredit macet yang berada dibawah $5 \%$ dan persentase CAR yang tinggi.

Perkembangan penyaluran kredit tertinggi yaitu pada triwulan II tahun 2010 yaitu sebesar $11,01 \%$, peningkatan penyaluran kredit pada triwulan ini terutama disebabkan oleh semakin kondusifnya perekonomian domestik yang sempat mengalami perlambatan pertumbuhan seiring dengan lesunya kegiatan dunia usaha akibat dampak krisis keuangan global pada tahun 2008. Sementara penyaluran kredit terendah pada periode ini terdapat pada triwulan I tahun 2016 yaitu sebesar $-3,53 \%$ yang disebabkan penurunan kinerja korporasi akibat perlambatan ekonomi yang juga berdampak pada penurunan kinerja keuangan rumah tangga.

Secara keseluruhan jumlah penyaluran kredit modal kerja menunjukkan tren yang terus meningkat, namun pada periode 2014-2018 setiap triwulan I perkembangan kredit selalu lebih rendah dibandingkan dengan triwulan sebelumnya. Penurunan perkembangan kredit pada triwulan I ini merupakan siklus yang umum terjadi diawal tahun yang mana setiap peningkatan kredit di akhir tahun akan menyebabkan penurunan kredit diawal tahun dan menurunnya permintaan kredit ini sejalan dengan masih rendahnya kebutuhan pembiayaan nasabah di awal tahun serta perbankan lebih selektif dalam menyalurkan kreditnya.

\section{Tingkat suku kredit bank umum di Indonesia}

Besar kecilnya tingkat suku bunga akan mempengaruhi minat masyarakat meminta penyaluran kredit. Penentuan besar kecilnya tingkat suku bunga kredit didasarkan dengan suku bunga dasar yang sudah ditetapkan oleh Bank Indonesia yang diberlakukannya pada tahun 2011 peraturan Nomor 13/5/DPNP tahun 2011 perihal transparansi Informasi Suku Bunga Dasar Kredit dengan tujuan yaitu untuk meningkatkan transaparansi mengenai karakteristik produk perbankan termasuk manfaat, biaya, dan risikonya untuk memberikan kejelasan kepada nasabah dan untuk meningkatkan Good Governance serta mendorong persaingan yang sehat dalam industri perbankan melalui terciptanya disiplin pasar yang lebih baik.

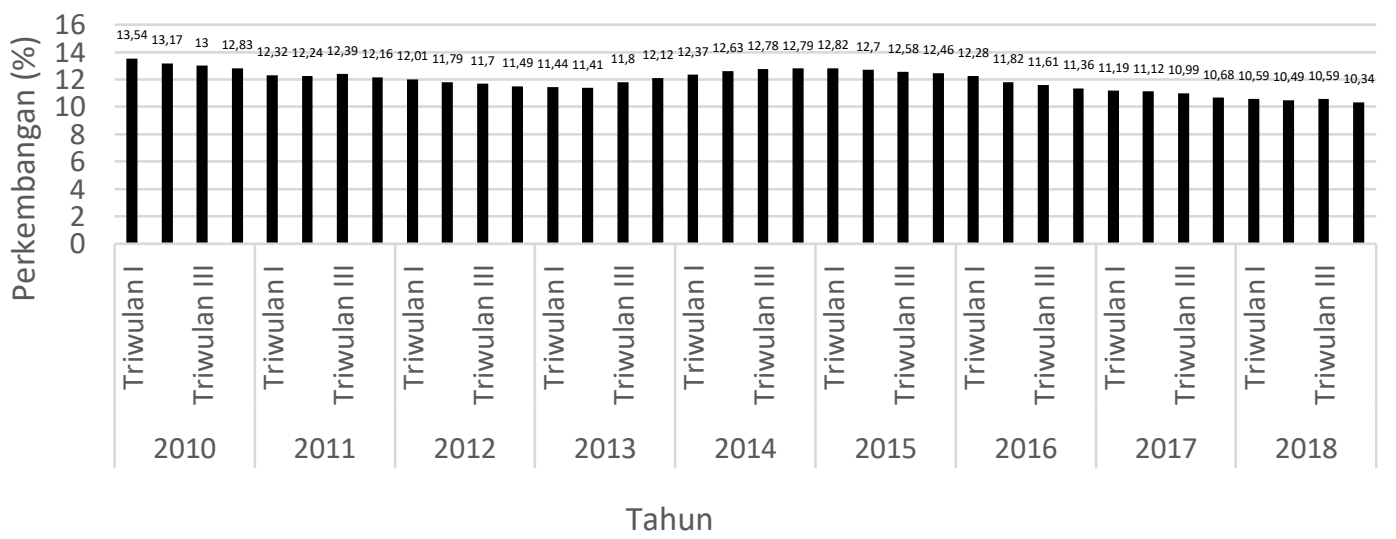

Sumber: Bank Indonesia (BI), 2019 (diolah)

Grafik 2. Perkembangan Tingkat Suku Bunga Bank Umum di Indonesia Periode 2010.I-2018.IV

Berdasarkan Grafik 2 rata-rata perkembangan tingkat suku bunga kredit periode 2010-2018 sebesar 11,93\%, dengan tingkat suku bunga tertinggi berada pada tahun 
2010, yaitu pada triwulan I sebesar 13,54\%, tingginya tingkat suku bunga ini dipicu masih tingginya persepsi risiko penyaluran kredit dan upaya bank untuk mempertahankan margin yang tinggi ditengah rendahnya permintaan kredit pada triwulan ini yaitu sebesar Rp 684,434 juta. Setelah adanya pemulihan ekonomi tingkat suku bunga kredit mulai menurun, penurunan tingkat suku bunga terus terjadi dari triwulan II tahun 2010 hingga triwulan II tahun 2013 sebesar 11,41\% penurunan ini disebabkan oleh penurunan suku bunga simpanan yang dipicu oleh membaiknya efisiensi perbankan secara umum. Penurunan tingkat suku bunga ini merupakan dampak positif dari diberkakukannya ketentuan Bank Indonesia yang mewajibkan bank untuk mempublikasikan data Suku Bunga Dasar Kredit (SBDK), sehingga ada transparansi mengenai penetapan tingkat suku bunga kredit kepada masyarakat. Pada triwulan III tahun 2013 tingkat suku bunga mengalami kenaikan hingga triwulan I tahun 2015, namun kenaikan ini tidak diikuti dengan penurunan penyaluran kredit. Tingkat suku bunga terendah pada periode ini yaitu pada triwulan IV tahun 2018 sebesar 10,34\%, penurunan tingkat suku bunga ini memicu peningkatan penyaluran kredit.

\section{Kredit macet bank umum di Indonesia}

Kredit bermasalah merupakan kegagalan pihak debitur memenuhi kewajibannya untuk membayar angsuran (cicilan) pokok kredit beserta bunga yang telah disepakati kedua belah pihak dalam perjanjian kredit (Hasibuan,2005). Tinggi rendahhnya tingkat kredit macet disebabkan oleh tingginya penyaluran kredit yang berisiko tanpa adanya pengawasan kredit, keadaan perekonomian pun juga berpengaruh terhadap tinggi rendahnya kredit macet yang dihasilkan oleh suatu bank. Rasio NPL (Non Perfoarming Loan) merupakan gambaran mengenai kondisi kredit macet yang dimiliki oleh suatu bank. Tingginya NPL akan mengakibatkan munculnya pencadangan yang lebih besar, sehingga pada akhirnya modal bank ikut terkikis untuk menutupi kerugian (Arif,2017). Sehingga, semakin besar persentase kredit macet maka bank memerlukan modal yang besar untuk menutupi kerugian yang disebabkan kredit macet serta menjalankan usahanya sebagai lembaga keuangan.

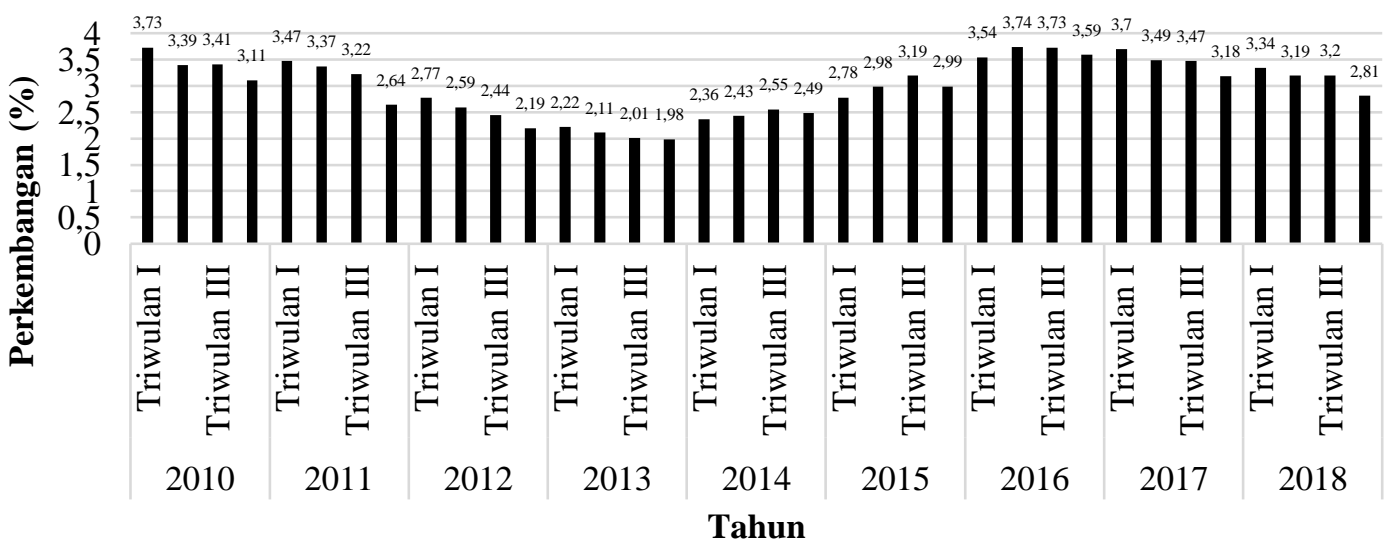

Sumber: Otoritas Jasa Keuangan (OJK), 2019 (diolah)

Grafik 3. Perkembangan kredit macet bank umum di Indonesia Periode 2010.I2018.IV.

Berdasarkan Grafik 3 rata-rata perkembangan kredit macet periode 2010-2018 sebesar 2,80\%. Secara keseluruhan perkembangan kredit macet bank umum di Indonesia masih berada dalam kategori aman dan terjaga hal ini dikarenakan perkembangan dari kredit macet pada periode ini secara keseluruhan berada dibawah 
batas wajar NPL yang ditetapkan Bank Indonesia yaitu sebesar 5\%. Perkembangan kredit macet tertinggi pada periode ini yaitu pada triwulan II tahun 2016 sebesar 3,74\%, peningkatan ini dipengaruhi oleh peningkatan kredit macet pada triwulan sebelumnya yaitu sebesar 3,54\% yang disebabkan oleh kelesuan ekonomi. Perkembangan kredit macet terendah yaitu pada triwulan IV tahun 2013 sebesar 1,98\%, rendahanya perkembangan kredit macet ini diikuti degan menurunnya penyaluran kredit di triwulan yang sama yang disebabkan meningkatnya tingkat suku bunga.

\section{Capital adequacy ratio (CAR)}

CAR merupakan indikator terhadap kemampuan bank untuk menutupi penurunan aktivanya sebagai akibat dari kerugian-kerugian bank yang disebabkan oleh aktiva yang berisiko (Sofyan,2016). Aktiva yang beresiko ini dapat berupa penyaluran kredit, karena setiap penyaluran kredit pasti mengandung risiko adanya kredit macet yang menyebabkan bank dapat mengalami kerugian sehingga harus memiliki modal yang cukup untuk menutupi kerugian tersebut.

Modal menjadi faktor penentu utama kapasitas pinjaman bank, karena modal tersebut bertujuan untuk menciptakan keseimbangan dan menyerap kerugian, serta guna menjaga kepercayaan nasabah pada bank (Oktaviani,2012). Semakin tinggi CAR maka semakin besar pula sumber daya financial yang dimiliki bank untuk mengantisipasi kerugian yang diakibatkan penyaluran kredit.

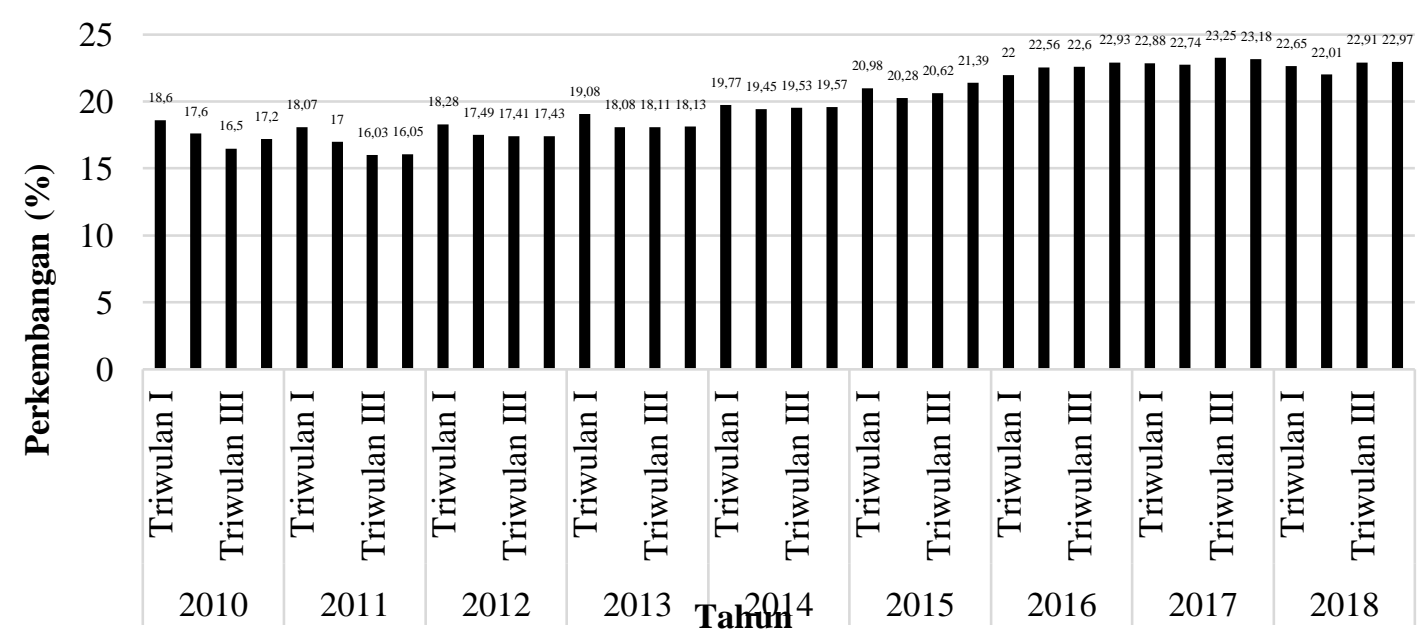

Sumber: Otoritas Jasa Keuangan (OJK), 2019 (diolah)

Grafik 4. Perkembangan CAR Bank Umum di Indonesia Periode 2010.I-2018.IV

Berdasarkan Grafik 4 rata-rata perkembangan CAR selama periode 2010-2018 yaitu sebesar 19,87\%. Perkembangan CAR tertinggi berada pada triwulan II tahun 2017 sebesar $23,35 \%$, tingginya rasio CAR ini berasal dari pertumbuhan nominal permodalan industri perbankan. Perkembangan CAR terendah berada pada triwulan III tahun 2011 sebesar $16,03 \%$, hal ini dipicu oleh penyaluran kredit yang meningkat pada triwulan tersebut. Secara keseluruhan rasio CAR yang dimiliki oleh bank umum pada periode ini berada jauh diatas ketetapan dari Bank Indonesa mengenai jumlah modal minimum yang harus dimiliki oleh bank yaitu sebesar 8\% dari ATMR (Aset Tertimbang Menurut Rasio) dengan tujuan untuk melindungi dana deposan dan mengemban berbagai fungsi lain dari bank. Kewajiban penyedeian modal minimum atau Capital Adequavy Ratio pada dasarnya suatu ukuran modal yang diharapkan dapat menjamin bahwa bank yang beroperasi secara internasional maupun nasiosal akan beroperasi secara baik atau Prudent (Taswan,2010). 


\section{Hasil regresi pengaruh tingkat suku bunga, kredit macet dan CAR terhadap penyaluran kredit modal kerja}

Untuk mengetahui bagaimana pengaruh dari tingkat suku bunga, kredit macet dan CAR terhadap penyaluran kredit mdal kerja, digunakan model regresi linier berganda dengan hasil regresi sebagai berikut :

Tabel 2. Hasil estimasi regresi

\begin{tabular}{ccccc}
\hline Variable & Coefficient & Std. error & t-Statistic & Prob. \\
\hline C & -536717.1 & 682202.8 & -0.786741 & 0.4372 \\
SBK & -91341.18 & 41457.31 & -2.203259 & 0.0349 \\
KM & -277630.4 & 58012.03 & -4.785738 & 0.0000 \\
CAR & 204012.3 & 16023.78 & 12.73184 & 0.0000 \\
R-squared & 0.914370 & & & \\
Adjusted R-squared & 0.906343 & & & \\
Log likelihood & -479.8861 & & & \\
F-statistic & 113.9010 & & & \\
Prob(F-statistic) & 0.000000 & & &
\end{tabular}

Sumber : Data diolah, 2020

Berdasarkan data tersebut diperoleh hasil estimasi model utama persamaan regresi linier berganda sebagai berikut :

\section{$P K_{t}=$-536717.1 - 91341.18 SBK - 277630.4 KM + 204012.3 CAR ${ }_{t}+e_{t}$}

Nilai koefisien konstanta (c) dari hasil persamaan tersebut sebesar -536717.1. Yang artinya jika tingkat suku bunga kredit, kredit macet dan CAR pada periode 2014.I2018.IV tidak mengalami perubahan atau tetap maka penyaluran kredit modal kerja akan turun sebesar 536717.1 miliar rupiah

Hasil regresi untuk variabel tingkat suku bunga kredit diperoleh nilai koefisien sebesar -91341.18. Artinya jika tingkat suku bunga mengalami kenaikan sebesar 1 persen maka penyaluran kredit modal kerja akan turun sebesar 91341.18 miliar rupiah begitupun sebaliknya, jika tingkat suku bunga turun maka penyaluran kredit akan naik. Hubungan yang negatif ini disebabkan karena tingkat suku bunga merupakan balas jasa atau harga yang harus dibayar nasabah kepada bank dari penyaluran kredit sehingga tingginya tingkat suku bunga akan menurunkan permintaan kredit yang akan menyebabkan turunnya penyaluran kredit. Tingginya tingkat suku bunga akan memberatkan pengembalian pembayaran kredit. Penyaluran kredit erat kaitannya dengan investasi, karena investor akan memilih untuk berinvestasi pada saat tingkat suku bunga yang rendah sehingga dapat mengoptimalkan keuntungan yang diperoleh dari investasi.

Hasil regresi untuk variabel kredit macet diperoleh nilai koefisien sebesar 277630.4. Artinya, ketika kredit macet meningkat I persen maka penyaluran kredit modal kerja akan turun sebesar 277630.4 miliar rupiah, begitupun sebaliknya jika nominal kredit macet turun maka penyaluran kredit modal kerja pun akan meningkat. Kredit macet berpengaruh negatif dan signifikan terhadap penyaluran kredit bank umum di Indonesia, yang artinya jika kredit macet naik maka bank akan menurunkan penyaluran kredit. Hal ini disebabkan besarnya persentase kredit macet akan menyebabkan bank mengalami kerugian dan menurunkan pendapatan laba yang akan diperoleh bank sehingga bank akan mengurangi penyaluran kredit ketika rasio kredit macetnya tinggi. Selain itu jika dilihat sisi nasabah, besarnya kredit macet ini akan 
menyebabkan bank lebih selektif menyalurkan kreditnya yang artinya tidak semua nasabah yang mengajukan permintaan penyaluran kredit akan disalurkan kreditnya, sehingga penyaluran kredit akan berkurang.

Hasil regresi untuk variabel CAR diperoleh nilai koefisien sebesar 204012.3. Artinya ketika CAR meningkat 1 persen maka, penyaluran kredit modal kerja naik sebesar 204012.3 miliar rupiah begitupun sebaliknya jika CAR turun 1 persen maka penyaluran kredit modal kerja juga akan turun. Ini berarti ada arah hubungan yang positif antar rasio CAR dengan penyaluran kredit. Rasio CAR mencerminkan kemampuan bank untuk menutupi aktiva yang mengandung risiko seperti penyaluran kredit sehingga modal yang dimiliki oleh bank akan berpengaruh terhadap perilaku bank dalam menyalurkan kreditnya, karena setiap penyaluran kredit memiliki risiko adanya kredit macet maka bank memerlukan modal yang cukup untuk mengantisipasi kerugian yang disebabkan oleh penyaluran kredit. Maka semakin besar rasio CAR yang dimiliki oleh suatu bank maka semakin besar pula kemampuan bank menyalurkan kreditnya.

\section{Uji asumsi klasik}

\section{Uji normalitas}

Berdasarkan uji normalitas diketahui bahwa nilai Jarque-bera sebesar 0,139181 dengan Probabilitas sebesar 0,932776 yang lebih besar dari tingkat $a=5 \%(0,05)$. Sehingga dapat disimpulkan bahwa residual terdistribusi normal yang artinya asumsi klasik tentang kenormalan telah dipenuhi.

\section{Uji multikolinearitas}

Uji multikolinieritas dilakukan untuk memastikan tidak hubungan yang kuat atau korelasi antara dua variabel bebas atau lebih dalam suatu regresi linier berganda. Suatu model regresi dapat dikatakan bebas multikoliniearitas jika nilai TOL $\leq 10$. Berikut merupakan hasil uji multikolinearitas.

Tabel 3. Hasil uji multikolinearitas

\begin{tabular}{cccc}
\hline Variable & $\begin{array}{c}\text { Coefficient } \\
\text { variance }\end{array}$ & $\begin{array}{c}\text { Uncentered } \\
\text { VIF }\end{array}$ & $\begin{array}{c}\text { Centered } \\
\text { VIF }\end{array}$ \\
\hline C & $4.65 \mathrm{E}+11$ & 671.4508 & NA \\
SBK & $1.72 \mathrm{E}+09$ & 354.7704 & 1.658028 \\
KM & $3.37 \mathrm{E}+09$ & 44.60301 & 1.372678 \\
CAR & $2.57 \mathrm{E}+08$ & 148.3210 & 2.061180 \\
\hline
\end{tabular}

Sumber: Data diolah,2020

Dari hasil uji diatas diperoleh nilai VIF suku bunga kredit (SBK) sebesar $1.658028<10$, nilai VIF kredit macet $(\mathrm{KM})$ sebesar $1.372678<10$, dan nilai VIF CAR sebesa $2.061180<10$. Maka ini menunjukkan semua variabel bebas dalam model bebas dari multikolinearitas.

\section{Uji autokorelasi}

Pengujian Autokorelasi dalam penelitian ini menggunakan metode uji BreuschGodfre dengan membandingkan nilai Prob. Chi-Square dengan tingkat alfa $\alpha(5 \%)$. Dari hasil regresi diperoleh nilai Prob. Chi-Square sebesar 0,0575 lebh besar dari tingkat alfa $5 \%(0,057>0,05)$ sehingga dapat disimpulkan dalam penelitian ini terdapat autokorelasi. 


\section{Uji heterokedastisitas}

Uji heteroskedastisitas ditujukan untuk mengetahui ada atau tidaknya ketidaksamaan varian dari residual pada model regresi. Metode pengujian heterokedastisitas dalam penelitian ini menggunakan uji White dengan hasil nilai Prob.Chi-Squarenya sebesar 0,3592 lebih besar dibandingkan tingkat alfa 5\% (0,3592 > 0,05). Sehingga dapat disimpulkan bahwa dari penelitian ini tidak terdapat heterokedastisitas.

\section{Pengujian hipotesis}

\section{Uji F-statistik}

Uji F ditujukan untuk mengetahui apakah seluruh variabel independen dalam penelitian ini bepengaruh terhadap variabel dependen secara signifika. Hasil regresi menunjukkan nilai F-statistic diperoleh sebesar 113.9010 dengan nilai F-tabel sebesar 2.89, maka $113.9010>2.89$ ( $\mathrm{F}$ hitung lebih besar dari $\mathrm{F}$ tabel). Apabila dilihat dari probabilitas, nilai Probabilitias F-statistik sebesar 0,0000000 lebih kecil dari $\alpha=5 \%$ $(0,0000000<0,05)$. Dengan demikian dapat disimpulkan bahwa, variabel tingkat suku bunga, kredit macet dan CAR secara bersama-sama berpengaruh signifikan terhadap penyaluran kredit modal kerja bank umum di Indonesia.

\section{Uji t-statistik}

Uji t ditujukan untuk mengetahui apakah variabel independent tingkat suku bunga, kredit macet dan CAR secara invidu berpengaruh terhadap variabel dependent penyaluran kredit. Pengujian ini dilakukan dengan membandingkan nilai probabilitas thitung $>\alpha(0.05)$. Jika $\mathrm{t}<0,05$, maka $\mathrm{H}_{0}$ ditolak dan $\mathrm{H}_{1}$ yang berarti variabel independennya berpengaruh signifikan terhadap variabel dependen begitupun sebaliknya jika Jika $\mathrm{t}<0,05$, maka $\mathrm{H}_{1}$ ditolak dan $\mathrm{H}_{0}$ yang berarti variabel indipenden tidak berpengaruh terhadap variabel dependen. Hasil regresi linier berganda untuk uji tstatistik dapat dilihat pada tabel berikut :

Tabel 4. Hasil regresi linier berganda uji t-statistik

\begin{tabular}{ccccc}
\hline Variabel & Coefficient & Std. Error & t-Statistic & Prob. \\
\hline C & -536717.1 & 682202.8 & -0.786741 & 0.4372 \\
SBK & -91341.18 & 41457.31 & -2.203259 & 0.0349 \\
KM & -277630.4 & 58012.03 & -4.785738 & 0.0000 \\
CAR & 204012.3 & 16023.78 & 12.73184 & 0.0000 \\
\hline
\end{tabular}

Sumber: Data diolah, 2020

Hasil uji t-statistik untuk variabel tingkat suku bunga kredit terhadap penyaluran kredit modal kerja menunjukkan nilai t-hitung sebesar -2.203259 dengan nilai t-tabel sebesar 1,69389 maka -2.203259>1,69389 (t-hitung lebih besar dari t-tabel) sehingga $\mathrm{H}_{0}$ ditolak yang berarti variabel tingkat suku bunga kredit berpengaruh signifikan terhadap penyaluran kredit bank umum di Indonesia. Bila dilihat nilai probabilitas, nilai probabilitas tingkat suku bunga kredit sebesar 0.0349, lebih kecil dari nilai $\alpha=5 \%$ $(0,0349<0,05)$ maka dapat disimpulkan variabel tingkat suku bunga kredit berpengaruh signifikan terhadap penyaluran kredit bank umum di Indonesia.

Uji t-statistik untuk variabel kredit macet terhadap penyaluran kredit modal kerja diketahui nilai t-hitung sebesar $-4.785738>1,69389$ (t-hitung lebih besar dari t-tabel) 
sehingga $\mathrm{H}_{0}$ ditolak yang berarti variabel kredit macet berpengaruh signifikan terhadap penyaluran kredit. Bila dilihat dari nilai probabilitas, nilai probabilitas kredit macet sebesar 0.000 , lebih kecil dari $\alpha=5 \%(0,0000<0,05)$ maka dapat disimpulkan variabel kredit macet berpengaruh signifikan terhadap penyaluran kredit bank umum di Indonesia.

Uji t-statistik untuk variabel CAR terhadap penyaluran kredit modal kerja diketahui nilai thitung sebesar $12.73184>1,69389$ (t-hitung lebih besar dari t-tabel) sehingga $\mathrm{H}_{0}$ ditolak yang berarti variabel CAR berpengaruh signifikan terhadap penyaluran kredit. Bila dilihat dari nilai probabilitas, nilai probablitias CAR sebesar 0.0000 , lebih kecil dari $\alpha=5 \%(0,0000<0,05)$ maka dapat disimpulkan variabel CAR berpengaruh signifikan terhadap penyaluran kredit bank umum di Indonesia.

\section{Koefisien determinasi $\left(\mathbf{R}^{\mathbf{2}}\right)$}

Nilai $\mathrm{R}^{2}$ menunjukkan seberapa besar pengaruh variabel independent yang digunakan dalam penelitian (tingkat suku bunga kredit, kredit macet dan CAR) terhadap variabel dependent penyaluran kredit modal kerja. Dari hasil regresi yang sudah dilakukan diperoleh hasil $\mathrm{R}^{2}$ sebesar 0.914370 , yang berarti variabel independent suku bunga kredit, kredit macet dan CAR mempengaruhi variabel dependent sebesar 91,43\% sedangkan $8,56 \%$ persen dipengaruhi oleh variabel lain yang tidak dimasukkan dalam penelitian.

\section{HASIL DAN KESIMPULAN}

\section{Kesimpulan}

Berdasarkan hasil analisis yang telah dilakukan, maka dapat disimpulkan perkembangan penyaluran kredit Bank Umum di Indonesia selama periode 2010.I2018.IV cenderung meningkat dengan rata-rata perkembangan 4,27\%. Perkembangan tingkat suku bunga kredit selama periode 2010.I-2018.IV mengalami sedikit fluktuasi dan cenderung menurun, dengan rata-rata perkembangannya yaitu sebesar $11,93 \%$. Perkembangan kredit macet selama periode 2010.I-2018.IV mengalami fluktuasi dan cenderung menurun, dengan rata-rata perkembangannya yaitu sebesar 2,80\%. Perkembangan Capital Adequacy Ratio (CAR) selama periode 2010.I-2018.IV relatif stabil dan cenderung naik, dengan rata-rata perkembangannya yaitu sebesar 19,87\%.

Berdasarkan hasil regresi dapat disimpulkan bahwa variabel tingkat suku bunga kredit, kredit macet dan CAR berpengaruh signfikan terhadap penyaluran kredit perbankan.

\section{Saran}

Berdasarkan hasil penelitian, maka saran yang dapat disampaikan oleh penulis yaitu bank sebagai otoritas moneter perlu menetapkan tingat suku bunga yang stabil dan relatif terjangkau bagi seluruh kalangan masyarakat untuk meningkatkan penyaluran kredit produktif seperti kredit modal kerja dan kredit investasi dalam mendukung perekonomian kearah yang lebih baik. Serta bank juga perlu memperhatikan jumlah kredit macet dan kecukupan modal yang dimiliki oleh bank untuk menghindari kerugian yang akan menyebabkan bank tidak bisa menjalankan kegiatan usahanya sebagai lembaga keuangan.

Salin itu perkembangan CAR dan kredit macet bank umum di Indonesia pada periode ini masih terjaga dengan baik. Tergambar dari rasio kredit macetnya masih berada dibawah $5 \%$ dan untuk rasio CAR berada jauh diatas $8 \%$. Dengan tingkat kredit 
macet yang masih terbilang rendah dan dengan tingkat modal yang tinggi bank seharusnya mampu mengoptimalkan penyaluran kredit terutama untuk kredit yang produktif.

\section{DAFTAR PUSTAKA}

Arif,D.(2017).Faktof-faktor yang mempengaruhi kebijakan penyaluran kredit perbankan pada bank umum di Indonesia Tahun 2010-2015.Skripsi Fakultas Ekonomi Universitas Negeri Yogyakarta : Yogyakarta.

Bank Indonesia. (2019). Statistik Ekonomi dan Keuangan Indonesia (SEKI). Diakses dalam www.bi.go.id, Tanggal 21 Januari 2019, Pukul 10.00 WIB

Ghozali, Imam.(2006).Aplikasi analisis multivariate dengan program SPSS (edisi Ke 4). Badan Penerbit Universitas Diponegoro: Semarang.

Hasibuan.,M.(2004). Dasar-dasar perbankan. PT. Bumi Aksara: Jakarta..

Hastuti.D; Edhie,Purnawan,M;\& S.Sunargo. (2018). Pengaruh variabel-variabel di sektor riil dan perbankan terhadap Shock Credit Default Swap (CDS) di Indonesia, e-Journal Perdagangan Industri dan Moneter, 6(2), 62-80

Kuncoro,M\&Suhardjono.(2002).Manajemen perbankann teori dan aplikasi. BPFEYogyakarta: Yogyakarta.

Lukman, D.(2009).Manajemen perbankan. Ghalia Indonesia: Jakarta.

M Maherika, R Nurjanah, E Achmad. (2019).Analisis pengaruh kredit perbankan terhadap pertumbuhan ekonomi Kota Jambi, e-Journal Perdagangan Industri dan Moneter, 7 (1), 121-132

Oktaviani dan Irene.(2012).Pengaruh DPK, ROA, CAR, NPL dan jumlah SBI terhadap penyaluran kredit perbankan (studi pada bank umum go public di Indonesia Periode 2008-2011).Diponegoro Journal of Management.1 (2), 430-438.

Otoritas Jasa Keuangan. (2010-2018).Statistik perbankan Indonesia. Otoritas Jasa Keuangan, Diakses dalam www.ojk.go.id, Tanggal 21 Januari 2019, Pukul 10.00 WIB

Sari,G.(2013).Faktor-faktor yang Mempengaruhi Penyaluran kredit bank umum di Indonesia (Periode Tahun 2008.1-2012.2).Jurnal EMBA.1 (3), 931-941.

Soetiono,K.S.,\&Setiawan,C.(2018).Literasi dan inklusi keuangan Indonesia. PT.Raja Grafindo Persada: Jakarta.

Sofyan, M.(2016).Pengaruh suku bunga kredit modal kerja, capital adequacy ratio dan loan to deposit ratio terhadap kredit modal kerja bank pengkreditan rakyat (studi kasus pada BPR di Kabupaten Provinsi Jawa Timur Tahun 2010-2015).Jurnal Ekonomika. 9 (2), 131-137.

Sugiyono.(2018).Metode penelitian manajemen. Alfabeta: Bandung

Taswan.(2010). Manajemen perbankan, konsep, teknik dan aplikasi. UPP STIM YKPN: Yogyakarta.

Wardhani.S.(2011). Analisis pengaruh spread tingkat suu bunga bnak, car dan npl terhadap penyaluran kredit UMKM oleh perbankan. Skripsi Fakultas Ekonomi.Universitas Diponegoro: Semarang. 